\title{
The effects of interleukin-10 and fibroblasts growth factor 2 in mice with toxic cuprizone model of demyelination
}

\author{
Labunets I. F., Rodnichenko A. E., Utko N. A., Panteleimonova T. M., Pokholenko Ya. O., Litoshenko Z. L., Butenko G. M. \\ State Institute of Genetic and Regenerative Medicine of the National Academy of Medical Sciences of Ukraine, Kyiv, Ukraine \\ e-mail: irina_labunets@ukr.net
}

\section{ABSTRACT}

Cytokines and growth factors exhibit neurotropic, anti-inflammatory and immunomodulatory properties, and therefore can affect the functioning of the nervous system at demyelinating disorders.

PURPOSE. To identify changes in T-lymphocytes, macrophages, oxidative stress and antioxidant defence factors in the brain, endocrine thymus function and behaviour of mice receiving neurotoxin cuprizone and recombinant human proteins: interleukin-10 (rhlL-10) and fibroblast growth factor-2 (rhFGF-2).

MATERIALS AND METHODS. 4-6-months-old 129/Sv mice received cuprizone with food every day for 3 weeks. From the $7^{\text {th }}$ day of cuprizone diet, they received different doses of rhIL-10 and rhFGF-2. The number of $C D 3^{+} T$-cells, macrophages, level of malondialdehyde, activity of antioxidant enzymes in the brain and the level of thymulin in the blood were determined. Behavioural reactions were assessed in the «open field» test.

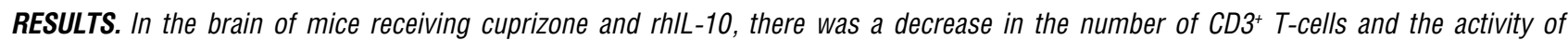
macrophages, which significantly increased under the influence of the toxin. After cytokine injections, the activity of superoxide dismutase, catalase and glutathione peroxidase increased significantly in the brain, as well as the level of thymulin in the blood. Motor, emotional and exploratory activity of mice, significantly suppressed by the cuprizone, was increased after the administration of rhIL-10. The effect of rhIL-10 on the test parameters is more pronounced at a dose of $5 \mu \mathrm{g} / \mathrm{kg}$ than $50 \mu \mathrm{g} / \mathrm{kg}$. After injections of rhFGF-2 in the mice with cuprizone diet, there is a decrease in the activity of brain macrophages and an increase of the level of thymulin in the blood depending on the dose of this factor; the motor activity of these animals increased regardless of the rhFGF-2 dose.

CONCLUSION. The injections of rhIL-10 and rhFGF-2 provide dose-dependent positive effects on the pathogenetic factors of experimental demyelinating pathology, as well as the functional state of the nervous system. Whereas, the injections of rhIL-10 have more pronounced effects.

KEY WORDS: cuprizone; interleukin-10; fibroblasts growth factor-2; T-lymphocytes; macrophages; antioxidant enzymes; thymulin; behavioural reactions

Currently, in the treatment of demyelinating pathology of the central nervous system (CNS), much attention is being focused on the search for the agents that promote the activation and directional differentiation of endogenous neural stem cells (NSCs) [1]. In particular, cytokines and growth factors, as important components of microenvironment for NSCs in the brain, affect the proliferative and differentiation potential of these cells [2, 3]. Thus, interleukin-10 (IL-10) is a growth factor for NSCs of subventricular zone of the lateral ventricles, whose functioning varies with demyelinating pathology [4-6]. In addition, IL-10 has a positive effect on the altered morphological state of the central nervous system in animals with some experimental demyelination models $[7,8]$. In the brain, the fibroblast growth factor-2 (FGF-2) exhibits the properties of the mitogenic factor for NSCs, inhibits apopto- sis of neurons and promotes remyelination by activating oligodendrocyte precursors $[9,10]$.

At demyelinating pathology of the CNS, changes in the regenerative potential of NSCs and functional state of the nervous system, as well as the link of these processes with damaging effects on the system of oxidative stress factors, activated microglia, macrophages and T-lymphocytes have been identified $[11,12]$. In the animals with a model of experimental autoimmune encephalomyelitis (EAE), interleukin-10 exhibits pronounced anti-inflammatory properties, affects the number of T-lymphocytes and neutrophils in peripheral blood $[13,14]$. This model also shows the effect of FGF-2 on the manifestation of neuroinflammation due to a decrease in functional activity of cerebral microglia and the infiltration of neural tissue by CD8 ${ }^{+}$T-cells $[9,10,15]$. 
However, the changes of T-lymphocytes, macrophages, oxidative stress factors in the brain as well as the functioning of the central nervous system in mice with toxic cuprizone demyelination model at the administration of IL-10 and FGF-2 remain unstudied. This model is widely used for the experimental study of the pathogenesis of demyelination and remyelination as well as mechanisms of behavioural reaction changes $[16,17]$. Since thymic hormones control the activity of T-lymphocytes and macrophages, it is also interesting to study the effect of IL-10 and FGF-2 on the thymic endocrine function, which varies in mice with a cuprizone model of demyelination $[12,18]$.

The literature data admit the dependence of the effects of cytokines and growth factors, in particular IL-10 and FGF-2, on their concentration $[4,19,20]$. Therefore, studies of the effect of different doses of IL-10 and FGF-2 on the pathogenetic factors of demyelination and function of the nervous system are important for reasoning the treatment schemes of this pathology.

The PURPOSE of the study is to determine the changes of T-lymphocytes, macrophages, balance of oxidative stress and antioxidant defence factors in the brain, thymus functions and behavioural responses in mice with a toxic model of demyelination under treatment with different doses of IL-10 and FGF-2.

\section{MATERIALS AND METHODS}

Animals. Experiments were performed on 4-6 months-old male $129 /$ Sv mice from the vivarium of the State Institute of Genetic and Regenerative Medicine of the NAMS of Ukraine. The mice were kept in standard conditions at a fixed light mode of 12:12. All experiments were carried out in accordance with the Law of Ukraine «On the Protection of Animals from Cruelty» and «European Convention for the Protection of Vertebrate Animals Used for Experimental and Other Scientific Purposes».

Models. As an experimental model of demyelination, we used the toxic cuprizone model $[12,17]$. To reproduce the cuprizone demyelination model, mice received neurotoxin cuprizone (Sigma, USA) with food $(0.2 \%$ of feed), daily for three weeks. The group of intact animals received the usual diet.

Human recombinant proteins. Recombinant human interleukin-10 (rhIL-10) and recombinant human fibroblasts growth factor-2 (rhFGF-2) were used in the study. They were obtained by the synthesis of the corresponding E.coli producers according to the standard method [21]. After lysis of bacterial cells, the target proteins were purified using ionexchange and affinity chromatography. The level of rhIL-10 in E.coli lysate and chromatographic fractions was evaluated by densitometry of electrophoregrams and subsequent analysis using Total Lab software (USA). The activity of rhFGF-2 was determined in the chick embryo chorioallantoic membrane angiogenesis assay.

Schemes of the use of rhlL-10 and rhFGF-2. Starting from the $7^{\text {th }}$ day of receiving cuprizone, rhIL-10 was injected intraperitoneally in $100 \mu \mathrm{l}$ of the vehicle (phosphate buffer) in single doses of $5.0 \mu \mathrm{g} / \mathrm{kg}$ and $50.0 \mu \mathrm{g} / \mathrm{kg}$, 3 injections in general, at 3-day intervals. rhFGF-2 was injected at a single dose $20 \mu \mathrm{g} / \mathrm{kg}$ and a different time of administration (total of 7 and 10 injections, at intervals of 24 hours). Control groups received cuprizone and injections of vehicle under similar schemes. The administration of recombinant proteins from the $7^{\text {th }}$ day of the cuprizone diet is due to the development of oligodendrocytes apoptosis at this period [3], as well as a significant decrease in the mice motor activity [17].

Experimental groups. Intact mice (usual diet); cuprizone and vehicle injections (control groups); cuprizone and injections of rhlL-10 at doses of $5.0 \mu \mathrm{g} / \mathrm{kg}$ and $50 \mu \mathrm{g} / \mathrm{kg}$ (three injections); cuprizone and injections of rhFGF-2 at a dose of $20 \mu \mathrm{g} / \mathrm{kg}, 7$ and 10 injections.

When phenotyping the brain cells by CD3 marker, phycoerythrin-conjugated monoclonal antibodies were used, according to the recommendations of the manufacturer (Becton Dickinson, USA). The homogenate of the brain was fixed for 10 minutes at room temperature with $4 \%$ solu- tion of paraformaldehyde in $0.1 \mathrm{M}$ phosphate buffer saline at $\mathrm{pH}$ 7.4. Cell permeabilization was performed for 15 minutes with the Perm/Wash buffer (Becton Dickinson, USA). Monoclonal antibodies at a dilution of 1:50 $\left(0.5 \mu \mathrm{g} / 10^{6} \mathrm{cells}\right)$, were added to the homogenate of the brain $\left(2 \cdot 10^{5}\right.$ cells in $50 \mu \mathrm{l})$. Measurements were performed by the BD FACSAria cell sorter, using BD FACS Diva 6.1 software (Becton Dickinson, USA).

Functional activity of macrophages. The brain was homogenized in PSB solution and placed in a $100 \mathrm{~mm}$ diameter Petri dish (Sarstedt, Germany) in the growth medium containing RPMI-1640, $10 \%$ fetal bovine serum, $2 \mathrm{mM}$ L-glutamine, penicillin and streptomycin (all reagents Sigma, USA). The cell suspension was cultured at $+37^{\circ} \mathrm{C}$ in a humidified atmosphere with $5 \% \mathrm{CO}_{2}$ for one hour. Then the cells that adhered to plastic were detached using the $0.25 \%$ trypsin and $0.02 \%$ Versene mixture (in 1:5 ratio). When the cells were completely detached from the substrate, $10 \%$ of fetal bovine serum was added to inhibit trypsin activity and the cells were carefully resuspended. After counting the cells in a Goryaev chamber, $0.2 \mathrm{~mL}$ cell suspension was layered on the cover glass $\left(2.5 \cdot 10^{6}\right.$ cells $/ \mathrm{mL}$ ) and incubated for 60 minutes in a humidified atmosphere with $5 \% \mathrm{CO}_{2}$ at $+37{ }^{\circ} \mathrm{C}$. After incubation, $0.2 \mathrm{ml}$ of suspension of latex in a RPMI-1640 medium (Sigma, USA) at concentration 2.5•108 particles $/ \mathrm{mL}$ was added to the monolayer and incubated for 45 minutes in a humidified atmosphere with $5 \% \mathrm{CO}_{2}$ at $+37^{\circ} \mathrm{C}$. After the incubation, the glass was fixed in $4 \%$ paraformaldehyde and stained by Romanowsky-Giemsa. In a light microscope, at least 200 macrophages were counted and the phagocytic index - the percentage of cells capable of phagocytosis of latex particles; and phagocytic number - the number of latex particles phagocyted by one macrophage were determined.

The endocrine function of the thymus was assessed by the level of the thymulin in the serum (log2 titer) [22].

Factors of oxidative stress and antioxidant defence. The level of malondialdehyde (MDA) in the mice brain was evaluated according to the intensity of the coloured trimethine complex formed between MDA and tiobarbituric acid (Sigma-Aldrich, Germany) and expressed in $\mathrm{nM} / \mathrm{mg}$ [23]. The activity of superoxide dismutase (SOD) and catalase was determined in the supernatants of the homogenates of the murine brain [24]. To determine the activity of SOD, a method based on the ability of the enzyme to suppress the adrenaline auto-oxidation in adrenochrome (Sigma-Aldrich, Germany) at pH $=10.2$ was used. SOD activity was expressed in standard units per $1 \mathrm{mg}$ of protein for $1 \mathrm{~min}$ (units $/ \mathrm{min} \bullet \mathrm{mg}$ ). The activity of catalase was determined from the kinetics of $\mathrm{H}_{2} \mathrm{O}_{2}$ degradation (Riedel-deHaën, Germany) and expressed in $\mu \mathrm{M}$ of utilized $\mathrm{H}_{2} \mathrm{O}_{2}$ per $1 \mathrm{mg}$ of protein for $1 \mathrm{~min}(\mu \mathrm{M} / \mathrm{min} \bullet \mathrm{mg})$. The level of protein was measured by the Lowry method, which is based on the reaction with copper in alkaline solution. The resulting substance is recovered by Folin's reagent (Sigma-Aldrich, Germany), which is accompanied by a change in blue color. All measurements were performed using a spectrophotometer $\mu$ Quant (Bio-Tek, USA).

Behavioural reactions were investigated in the "open field» test, which allows to assess motor, emotional and exploratory activity of animals [25]. Horizontal motor activity was investigated by the number of crossed squares, emotional - by the number of boluses, and exploratory - by the number of rearings and explored holes. Indicators of behaviour in experimental mice group were recorded for 3 minutes.

The statistical analysis was assessed using Student's t-test. The results are presented as means and standard error of mean $(M \pm m)$. The difference between the parameters was considered statistically significant at a value of $p<0.05$. The analysis of the data was performed using the Statistica 7.0 software (StatSoft Inc., USA).

\section{RESULTS AND DISCUSSION}

Effects of different doses of rhlL-10 on macrophages, T-lymphocytes, oxidative stress and antioxidant defence of the brain, and thymus function in mice with a cuprizone demyelination model. 
After receiving cuprizone, the number of T-lymphocytes, active macrophages and the level of MDA in the brain of mice significantly increase (Fig. 1, 2). After the administration of rhlL-10 at a dose of $5.0 \mu \mathrm{g} / \mathrm{kg}$, the number of T-lymphocytes and the activity of macrophages decrease, whereas the activity of SOD, catalase and the level of thymulin in the blood increases (Fig. 1, 2). RhlL-10 at a dose of $50.0 \mu \mathrm{g} / \mathrm{kg}$ has a more pronounced suppressive effect on the number of T-cells in the brain, and increases the level of the thymulin in the blood (Fig. 1). The values of all other test parameters after administration of rhIL-10 at a dose of $50.0 \mu \mathrm{g} / \mathrm{kg}$ do not differ from those in the control group with cuprizone (Fig. 1, 2).

Consequently, the effect of rhlL-10 on T-lymphocytes, macrophages and antioxidant enzymes of the brain of mice with cuprizone diet depends on its dose. In this case, positive changes in most of the studied parameters are observed at a rhlL-10 dose of $5.0 \mu \mathrm{g} / \mathrm{kg}$.

The effects of different doses of rhlL-10 on behavioural responses in mice with a cuprizone model of demyelination.

Cuprizone treatment leads to a significant decrease in the values of motor, emotional and exploratory activity of mice (Fig. 3). After injections of rhlL-10 at a dose of $5.0 \mu \mathrm{g} / \mathrm{kg}$, the values of the studied parameters significantly increase, whereas the number of boluses and vertical stands increases to the level of intact mice (Fig. 3). The effect of rhIL-10 at a dose of $50.0 \mu \mathrm{g} / \mathrm{kg}$ had similar changes in behavioural reaction parameters, except for the number of rearings.

Thus, regardless of the dose, injections of rhIL-10 improve the motor and emotional activity of animals damaged by cuprizone treatment. However, the dose of $5.0 \mu \mathrm{g} / \mathrm{kg}$ cytokine was found to be more effective in increasing the exploratory activity of animals with a cuprizone mode of demyelination.
Macrophages, T-lymphocytes, markers of oxidative stress and antioxidant defence in the brain, thymus function in mice receiving cuprizone and various doses of rhFGF-2.

It has been determined that in animals receiving cuprizone, which were administered rhFGF-2 at a dose of $20 \mu \mathrm{g} / \mathrm{kg}$ (7 injections), there are only changes in cellular and humoral factors of the immune system, in particular, the activity of macrophages of the brain significantly decreases and thymulin level in blood increases (Table 1). The growth factor at a dose of $20 \mu \mathrm{g} / \mathrm{kg}$ (10 injections) causes an increase in the level of the thymulin in the blood. In such animals, the activity of macrophages and the number of T-lymphocytes in the brain remain increased (Table 1).

Thus, in mice with a cuprizone diet rhFGF-2 exhibit a dose-dependent effect on the activity of macrophages of the brain and the function of thymus.

Behavioural responses in mice receiving cuprizone and various doses of rhFGF-2. A significant increase in horizontal motor activity of mice receiving cuprizone with injections of different doses of rhFGF-2 was found (Table 2). However, the motor activity of the mice remained lower than in animals of the intact group $(p<0.05)$. The parameters of emotional and exploratory activity did not differ between the experimental groups of mice. Consequently, irrespective of the dose, rhFGF-2 injections improve the motor activity of the mice with a cuprizone model of demyelination.

Thus, the obtained results indicate that rhIL-10 and rhFGF-2 influence the studied pathogenetic factors of demyelinating pathology induced by neurotoxin cuprizone, as well as altered function of the central nervous system. The effect of rhIL-10 and rhFGF-2 is dose-dependent.

Expressed anti-inflammatory properties of IL-10 at such an experimental demyelinating CNS pathology as EAE are associated with
$\mathrm{CD}^{+}$

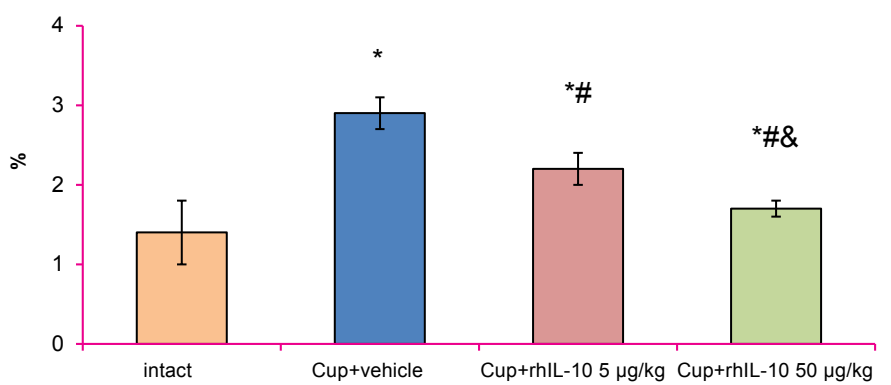

Phagocytic number

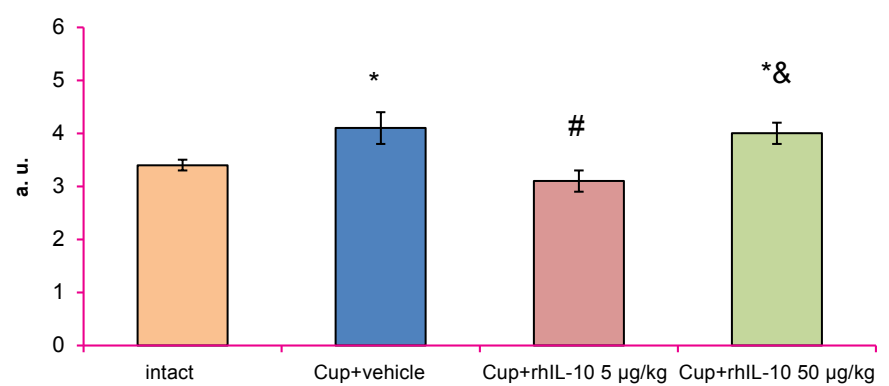

Phagocytic index

B

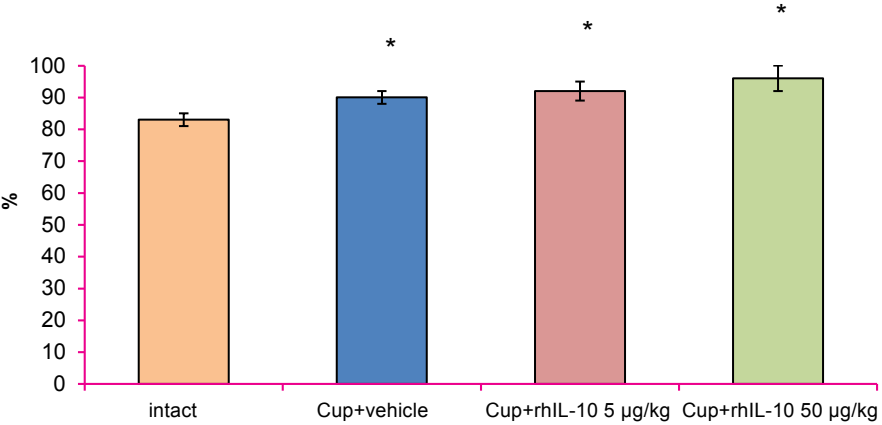

Thymulin

D

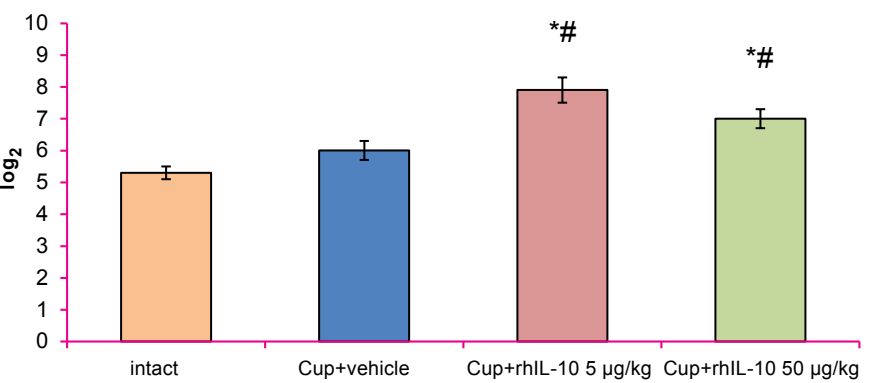



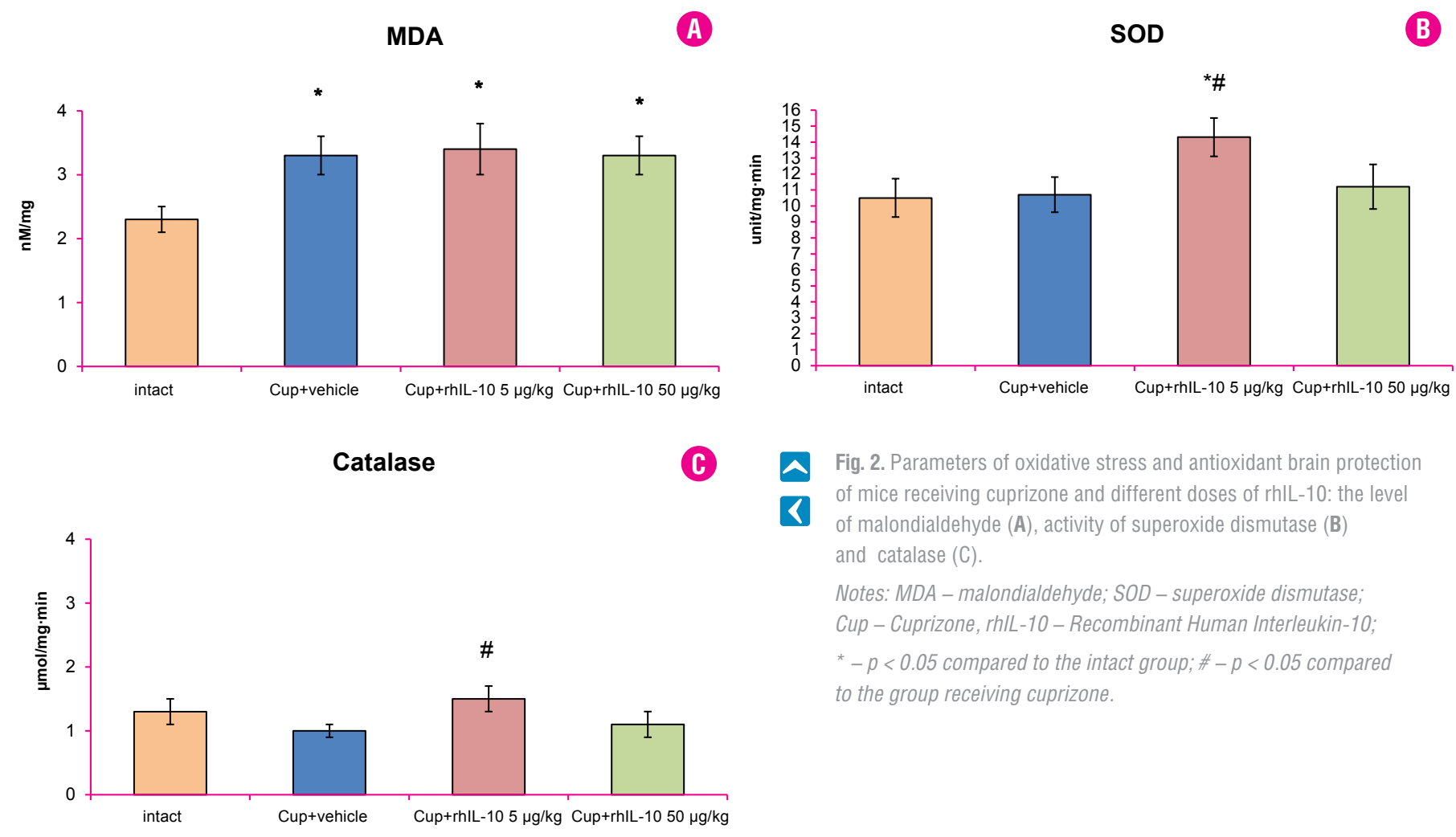

Horizontal motor activity

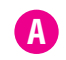

Emotional activity
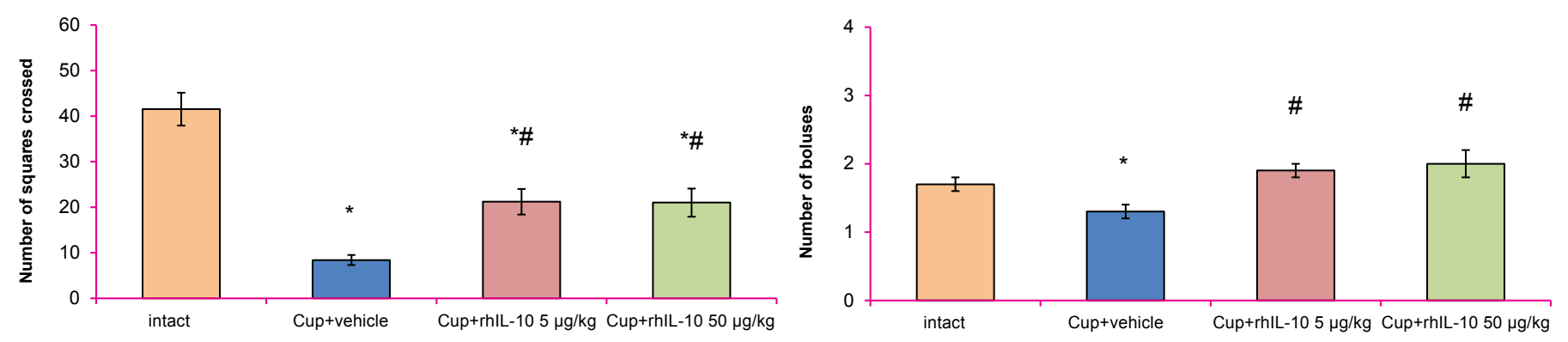

Exploratory activity

(C)
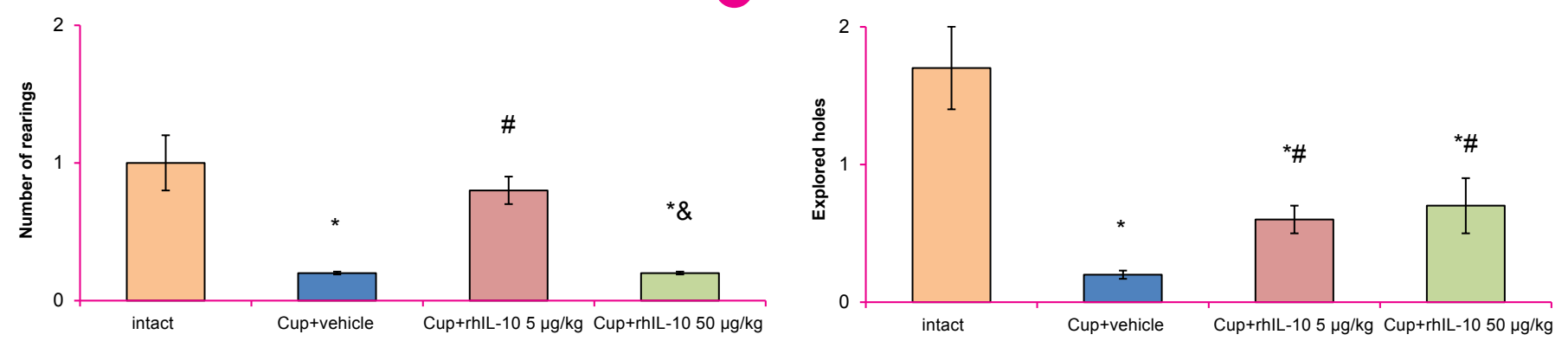

A Fig. 3. Behavioural parameters of mice in the «open field» test: horizontal motor activity (A), emotional activity (B), exploratory activity (C, D). Notes: Cup - Cuprizone, rhlL-10 - Recombinant Human Interleukin-10;

${ }^{*}-p<0.05$ compared to the intact group; \# $-p<0.05$ compared to the group receiving cuprizone; $\&-p<0.05$ compared to the dose of rhll-10 $5 \mu \mathrm{gg} / \mathrm{kg}$. 
a decrease expression and synthesis of proinflammatory cytokines (tumor necrosis factor TNF-a, interferon- $\gamma$, IL-1 $\beta$, IL-2, IL-6) as well as the activity of microglia/macrophages and type $1 \mathrm{~T}$-helper cells in the brain $[26,27]$.

We have shown the suppressive effect of rhIL-10 on the number of T-lymphocytes and activity of macrophages of the brain on the cuprizone model of demyelination. There is also an important enhancement of the endocrine function of thymus in such mice, which can be explained by a decrease in the synthesis of corticosterone in the adrenal glands under the influence of the cytokine [28]. Literature data testify to the regulatory effects of thymulin on the activity of macrophages, the differentiation and functioning of T-lymphocytes [18]. Animals with a model of neuroinflammation show the stimulating effect of this hormone on IL-10 synthesis in the brain against the suppression of the synthesis of TNF- $\alpha$ and IL-1 $\beta$ [29]. Macrophages and T-lymphocytes have been shown to be the source of proinflammatory cytokines and active forms of oxygen that damage nerve cells of the brain $[3,11,30]$.

The increase of the antioxidant enzymes activity in the brain of mice receiving cuprizone with rhIL-10 testify to an increase in the antioxidant defence of the neural tissue. Studies by Lattorre et al. also show the possibility of activating the effect of IL-10 on antioxidant enzymes in the cells under the impact of prooxidant damaging factors [19].

It is important that after the injections of rhIL-10, changes in the number of T-lymphocytes, macrophages and the activity of antioxidant enzymes in the brain, as well as the level of thymulin in the blood, correlate with the improvement of behavioural responses suppressed by cuprizone. Positive changes in the function of the central nervous system, caused by rhlL-10, indicate the involvement of the immune system and antioxidant defence in their formation.

At the same time, the dose-dependent effect of rhlL-10 on the immune system, antioxidant defence and behaviour in mice with a cuprizone demyelination model draws attention; when a dose of $5.0 \mu \mathrm{g} / \mathrm{kg}$ was more effective. On the contrary, in restoring the structure of neurons in the central nervous system of such mice, the dose of rhlL-10 $50.0 \mu \mathrm{g} / \mathrm{kg}$ was found to be more effective [8]. Unequal results of the impact of different doses of rhIL-10 on the structure of the central nervous system can be partly explained by the involvement in such conditions of various ways of its implementation. Thus, the results of positive changes in behavioural responses after the administration of a lower dose of rhIL-10 against the background of latent structural changes in the CNS neurons are consistent with the hypotheses of Serra-de-Oliveira et al. [31]. They admit the importance of changes in the factors of neuroinflammation in the pathogenesis of not only suppression of the functions of the nervous system in demyelinating pathology, but also its recovery. At the same time, after administration of a larger dose of rhIL-10, we observed significant positive morpho-functional changes in the central nervous system, but with less pronounced changes in neuroinflammatory factors compared to the less cytokine dose. It is possible that, in this case, changes in the neurons structure are due to the activating effect of rhIL-10 on the synthesis of brain neurotrophic factors. The authors have shown that IL-10 provides survival of damaged neurons of the central nervous system by activating the synthesis of neurotrophic factors by glial cells $[32,33]$.

FGF-2 is a multifunctional growth factor with pronounced effects on the angiogenesis and the functioning of NSCs in the main zones of neurogenesis [10]. At the same time, literature data on changes in neurogenesis and myelogenesis under the impact of FGF-2 are ambiguous, namely, there was observed the activation of these processes, and their inhibition $[9,34]$. In our experiment, we observed a significant increase in motor activity of mice receiving cuprizone with rhFGF-2. According to our preliminary results, in mice that received 7 injections of this growth factor simultaneously, the number of intact neurons in the cerebral cortex increased (1.5 times), which allows to treat the effect of rhFGF-2 in such mice as neuroprotective.

One of the possible ways of FGF-2 protecting effect in demyelinating pathology is the change in the number and/or activity of cells involved in the neuroinflammation [10]. In this case, FGF-2 affects the cells of microglia/macrophages of the brain through the surface glycoprotein CD200, which regulates the activation of these cells [9]. According to Gudi et al. [3], FGF-2 enhances myelination by direct impact on oligodendrocytes, and indirectly through other types of cells that suppress it (astrocytes, microglia cells). Our findings regarding the decline of brain macrophages activity after injections of rhFGF-2 into mice with a cuprizone diet confirm the opinion of these authors.

However, we did not observe a decrease in the number of T-cells in the brain of mice that received cuprizone with rhFGF-2, although the authors found that this effect was observed in animals with EAE [9]. Moreover, the number of T-lymphocytes in the brain of the mice with cuprizone diet after ten injections of rhFGF-2 was even 1.4 times higher than that of control group mice. The results indicate the importance of implementing the effects of rhFGF-2, as well as rhlL-10, depending on their course dose at demyelinating CNS pathology. Perhaps, due to the use of different doses of FGF-2 in this pathology, there is a difference in the results of researchers regarding the direction of its effect on myelogenesis.

Since, according to the literature, FGF-2 and IL-10 influence myeloand neurogenesis, and their expression in the brain is gradually enhanced by the reproduction of the cuprizone demyelination model [3], we compared the obtained effects of rhlL-10 and rhFGF-2 in mice with cuprizone diet.

Table 1. Relative number of CD3 ${ }^{+}$cells, macrophage activity, oxidative stress and antioxidant defence in the brain, as well as the amount of thymulin in the blood of mice.

GROUP

\begin{tabular}{|c|c|c|c|c|}
\hline \multirow[b]{2}{*}{ PARAMETER } & \multicolumn{4}{|c|}{ GROUP } \\
\hline & INTACT & $\begin{array}{l}\text { CUPRIZONE + } \\
\text { VEHICLE }\end{array}$ & $\begin{array}{c}\text { CUPRIZONE + rhFGF-2 } \\
20 \mu \mathrm{g} / \mathrm{kg},(7 \text { INJECTIONS) }\end{array}$ & $\begin{array}{c}\text { CUPRIZONE + rhFGF-2 } \\
20 \mu \mathrm{g} / \mathrm{kg},(10 \text { INJECTIONS) }\end{array}$ \\
\hline CD3+, \% & $1.9 \pm 0.1$ & $2.5 \pm 0.1^{*}$ & $2.8 \pm 0.2^{*}$ & $3.5 \pm 0.5^{\star}$ \\
\hline Phagocytic index, \% & $80.2 \pm 2.1$ & $87.3 \pm 2.4^{*}$ & $88.1 \pm 2.3^{*}$ & $90.2 \pm 3.1^{*}$ \\
\hline Phagocytic number, a. u. & $3.4 \pm 0.1$ & $4.3 \pm 0.3^{\star}$ & $3.0 \pm 0.2 \#$ & $3.8 \pm 0.1^{\star}$ \\
\hline Thymulin, log2 & $5.7 \pm 0.3$ & $6.5 \pm 0.3$ & $7.3 \pm 0.2^{\star} \#$ & $7.0 \pm 0.3^{\star}$ \\
\hline MDA (nM/mg) & $2.8 \pm 0.2$ & $3.4 \pm 0.2^{*}$ & $3.5 \pm 0.2^{*}$ & $3.3 \pm 0.1^{*}$ \\
\hline SOD (unit/mg•min) & $11.6 \pm 1.2$ & $11.4 \pm 1.4$ & $10.5 \pm 1.8$ & $10.2 \pm 1.6$ \\
\hline Catalase $(\mu \mathrm{mol} / \mathrm{mg} \bullet \mathrm{min})$ & $1.4 \pm 0.2$ & $1.2 \pm 0.1$ & $1.3 \pm 0.1$ & $1.4 \pm 0.2$ \\
\hline
\end{tabular}

Notes: rhFGF-2 - recombinant human fibroblast growth factor, MDA - malondialdehyde; SOD - superoxide dismutase; 


\begin{tabular}{|c|c|c|c|c|}
\hline \multirow[b]{2}{*}{ PARAMETER } & \multicolumn{4}{|c|}{ GROUP } \\
\hline & INTACT & $\begin{array}{l}\text { CUPRIZONE + } \\
\text { VEHICLE }\end{array}$ & $\begin{array}{c}\text { CUPRIZONE + rhFGF-2 } \\
20 \mu \mathrm{\mu g} / \mathrm{kg} \text {, (7 INJECTIONS) }\end{array}$ & $\begin{array}{c}\text { CUPRIZONE + rhFGF-2 } \\
20 \mu \mathrm{\mu g} / \mathrm{kg} \text {, (10 INJECTIONS) }\end{array}$ \\
\hline Number of squares crossed & $40.8 \pm 3.4$ & $17.0 \pm 1.5^{\star}$ & $28.1 \pm 3.1^{*} \#$ & $30.0 \pm 3.2^{*} \#$ \\
\hline Number of boluses & $1.8 \pm 0.2$ & $1.2 \pm 0.1^{*}$ & $1.3 \pm 0.1^{\star}$ & $1.1 \pm 0.1^{*}$ \\
\hline Number of rearings & $0.8 \pm 0.1$ & $0.2 \pm 0.02^{\star}$ & $0.3 \pm 0.01^{*}$ & $0.3 \pm 0.03^{*}$ \\
\hline Explored holes & $1.3 \pm 0.2$ & $0.3 \pm 0.1^{*}$ & $0.5 \pm 0.1^{*}$ & $0.4 \pm 0.1^{*}$ \\
\hline
\end{tabular}

Notes: rhFGF-2 - recombinant human fibroblast growth factor;

* $-p<0.05$ compared to the intact group; $\#-p<0.05$ compared to the cuprizone group.

Such a comparison allowed us to determine both the general features of their effect and differences. The general feature of rhIL-10 and rhFGF-2 effects during the cuprizone administration is the positive changes in the activity of macrophages in the brain, the level of thymulin in the blood and the motor activity of animals. At the same time, rhlL-10 was also effective in changing the number of T-lymphocytes and antioxidant defence of the brain. Our results deepen the idea of the role of anti-inflammatory cytokines (IL-10) and growth factors (FGF-2) in the pathogenesis of demyelinating CNS pathology. The fact that dosedependent effects of rhIL-10 and rhFGF-2 in this pathology may be relevant when substantiating the approaches to its therapy. In particular, a similar effect on the changed parameters, and in some cases more pronounced, may be obtained by using a less course dose of cytokine and growth factor.

\section{CONCLUSION}

1. Injections of rhlL-10 into mice with a cuprizone model of demyelination show a dose-dependent effect on changes in the number of T-lymphocytes, macrophage activity and antioxidant enzymes in the brain, and in the level of thymulin in the blood.

2. Recombinant human IL-10 improves motor and emotional activity of mice, which was suppressed by the use of a cuprizone. The increase of the exploratory activity of these animals depended on the dose of cytokine.

3. In mice with a cuprizone diet, the injections of rhFGF-2 causes positive changes in the activity of macrophages of the brain, the level of thymulin in the blood and motor activity. The effect of this growth factor on the activity of macrophages of the brain and the amount of thymulin in the blood depends on its dose.

4. More effective changes in the studied parameters in experimental mice with the use of lower doses of rhlL-10 and rhFGF-2 indicate the importance of taking into account the dose-dependent effect of these factors in substantiating the approaches to the therapy of demyelinating pathology.

1. Huang L, Wang G. The effects of different factors on the behaviour of neural stem cells. Stem cells international. 2017. Article ID9497325. https://doi. org/10/1155/2017/9497325.

2. Huang $Y$, Dreyfus CF. The role of growth factors as a therapeutic approach to demyelinating disease. Exp Neurol. 2016; 283(ptB):531-540. D0I:10.1016/j.exp. neurol.2016.02.023

3. Gudi V, Gingele S, Skripuletz Th, Stangel M. Glial response during cuprizon-induced de- and remyelination in the CNS: lessons learned. Front Cell Neurosci. 2014; 8 (Article 73). DOI: 10.3389/fncel.2014.00073.

4. Perez-Asensio FJ, Perpiñá U, Planas AM, Pozas E. Interleukin-10 regulates progenitor differentiation and modulates neurogenesis in adult brain. J Cell Sci. 2013; 126:4208-4219. DOI: $10.1242 /$ jcs.127803.

5. Guglielmetti C, Praet J, Rangarajan J, Vreys R, DeVocht N, Maes F, et al. Multimodal imaging of subventricular zone neural stem/progenitor cells in the cuprizone mouse model reveals increased neurogenic potential for the olfactory bulb pathway, but no contribution to remyelination of the corpus callosum. Neuroimage. 2013: 1053-8119(13):000849-5. DOI:10.1016/j.neuroimage.2013.07.080

6. Labunets I, Rodnichenko A, Melnyk N, Utko N. Neuroprotective effect of melatonin in mice with toxic cuprizone model of demyelination and possible pathways of its realization. Cell and Organ Transplantology. 2018; 6(2):145-151. DOI:10.22494/cot.v6i2.87.

7. Pichkur LD, Verbovska SA, Vaslovich WV, Akinola ST, Deryabina OG, Pokholenko YO. Vpliv ksenogennoï transplantatsiï mezenkhimal'nikh stovburovikh klitin ta interleykinu-10 na perebig alergiynogo entsefalomielitu [Effect of xenogeneic mesenchymal stem cells transplantation and interleukin-10 on the course of allergic encephalomyelitis]. Ukraïns'kiy nevrologichniy zhurnal - Ukrainian Neurological Journal. 2018;1:56-63. [In Ukrainian]

8. Labunets IF, Melnyk NO, Rodnichenko AE, Pokholenko YO. Effect of recombinant human IL-10 on the structure of neurons of the central nervous system and behavioral responses in mice with a cuprizone model of multiple sclerosis. Cell and Organ Transplantology. 2017; 5(2): 240-241.

9. Rottlaender A, Villwock H, Addicks K, Kuerten $S$. Neuroprotective role of fibroblast growth factor-2 in experimental autoimmune encephalomyelitis. Immumology. 2011; 133:370-378. DOl:10.1111/j.1365-2567.2011.03450.x

10. Woodbury ME, Ikezu T. Fibroblast growth factor-2 signaling in neurogenesis and neurodegeneration. J Neuroimmune Pharmacol. 2014; 9(2):92-101. D0l:10.1007/ s11481-013-9501-5. 
11. Abdurasulova IN, Klimenko VM. Rol' immunnykh i glial'nykh kletok v protsessakh neyrodegeneratsii [The role of immune and glial cells in the processes of neurodegeneration]. Med akadem zhurnal - Med acad journal. 2011; 11(1):12-29. [In Russian]

12. Labunets IF. Izmeneniya endokrinnoy funktsii timusa, makrofagov i T-limfotsitov golovnogo mozga u myshey raznogo vozrasta posle vvedeniya neyrotoksina kuprizona i tsitokina [Changes of thymic endocrine function, brain macrophages and T-lymphocytes in mice of different ages after administration of neurotoxin cuprizone and cytokine]. Mezhdunar nevrol zhurn - International Neurological Journal. 2018; 4(98):155-161. D0I:10.22141/2224-0713.4.98.2018.139434. [In Russian]

13. Rudenko VA, Gnedkova IO, Pichkur LD, Verbovska SA, Pokholenko YO. Vpliv ksenogennoï transplantatsiï mezenkhimal'nikh stovburovikh klitin ta IL-10 na pokazniki klitinnogo imunitetu u shchuriv z eksperimental'nim alergichnim entsefalomiєlitom [Effect of xenogeneic mesenchymal stem cells transplantation and interleukin-10 on the parameters of cellular immunity of rats with allergic encephalomyelitis]. Zb nauk prats' spivrob. NMAPO imeni PL Shupika. 2014; 23(2):434-441. [In Ukrainian]

14. Meng J, Ni J, Wu Z, Jiang M, Zhu A, Qing H, et al. The Critical Role of IL-10 in the Antineuroinflammatory and Antioxidative Effects of Rheum tanguticum on Activated Microglia Oxidative medicine and cellular longevity. 2018; 6:1-12. DOI: 10.1155/2018/1083596.

15. Noda M, Takii K, Parajuli B, Kawanokuchi J, Sonobe $Y$, Takeuchi $H$, et al. FGF-2 released from degenerating neurons exerts microglial-induced neuroprotection via FGFR3-ERK signaling pathway. J Neuroinflammation. 2014. 11:76. http://www.jneuroinflammation.com/content/11/1/78.

16. Praet J, Guglielmetti C, Berneman Z, Van der Linden A, Ponsaerts $P$. Cellular and molecular neuropathology of the cuprizone mouse model: Clinical relevance for multiple sclerosis. J Neubiorev. 2014; 47: 485-505. doi.org/10.1016/j.neubiorev.2014.10.004.

17. Labunets IF. Mozhlivosti ta perspektivi vikoristannya toksichnoï kuprizonovoï modeli demiєlinizatsiï in vivo ta in vitro v eksperimental'niy i klinichniy nevrologiï (oglyad literaturi ta vlasni doslidzhennya) [Possibilities and prospects of the application of the in vivo and in vitro toxic cuprizone model for demyelination in experimental and clinical neurology (literature review and own research results)]. Ukraïns'kiy nevrologichniy zhurnal - Ukrainian Neurological Journal. 2018; 2:63-68. D0I: https://doi. org/10.30978/UNZ2018263 [In Ukrainian]

18. Csaba G. The immunoendocrine thymus as a pacemaker of lifespan. Acta Microbiol Immunol Hung. 2016; 63(2):139-158. D0I: 10.1556/030.63.2016.2.1.

19. Latorre E, Matheus N, Layunta E, Alcalde Al, Mesonero JE. IL-10 counteracts proinflammatory mediator evoked oxidative stress in Caco-2 cells. Mediators of Inflammation. 2014. Article ID 982639. http://dx.doi.org/10.1155/2014/98.

20. Shim KY, Saima FT, Eom YW. High Dose of FGF-2 Induced Growth Retardation via ERK1/2 De-phosphorylation in Bone Marrow-derived Mesenchymal Stem Cells. Biomed Sci Letters. 2017; 23:49-56. https://doi.org/10.15616/BSL.2017.23.2.49.

21. The Protein Protocols Handbook / Ed. J. M. Walker. Totowa, 2002. 1139 p.

22. Labunets IF, Rodnichenko AY, Vasyliev RG. Sposobnost' kletok-predshestvennits granulotsitov i makrofagov kostnogo mozga myshey raznykh liniy k obrazovaniyu koloniy in vitro pri izmenenii soderzhaniya timulina v organizme i v kul'ture kletok [Capacity of bone marrow granylocyte and macrophage precursors in mice of different strains for in vitro colony formation under changed thymuline level in the organism and cell cultures]. Geny \& kletki - Genes \& Cells. $2017 ; 12$ (2):97-103. DOI: 10.23868/201707021. [In Russian]

23. Uchiyama M, Mihara M. Determination of malonaldehyde precursor in tissues by thiobarbituric acid test. Anal Biochem. 1978; 86(1):271-278.

24. Labunets IF, Talanov SA, Vasilyev RG, Rodnichenko AE, Utko NA, Kuzminova IA, et al. Thymic hormones, antioxidant enzymes and neurogenesis of bulbus olfactorius in rats with parkinsonism: the effect of melatonin. Int. J. Phys. Pathophys. 2016; 7(4):285-298. D0I: 10.1615/IntJPhysPathophys.v7.i4.10.

25. Amikishieva AV. Povedencheskoe fenotipirovanie: sovremennye metody i oborudovanie. [Behavioural phenotyping: modern methods and equipment]. Vestnik VOGiS - VOGiS Herald. 2009; 13(3):529-542.

26. Strle K, Zhou JH, Shen WH, Broussard SR, Johnson RW, Found GG, et al. Interleukin-10 in the brain. Crit Rev Immunol. 2001; 21(5):427-449. D0I: 10.1615/ CritRevImmunol.v21.i5.20.

27. Klose J, Schmidt NO, Melms A, Dohi M, Miyazaki J, Bischaf F. Suppression of experimental autoimmune encephalomyelitis by interleukin-10 transduced neural stem/ progenitor cells. J Neuroinflammation. 2013; 10:117. DOI: 10.1186/1742-2094-10-117.

28. Koldric-Zivanovic N, Tu H, Juelich TL, Rady P L, Tyring S K, Hudnall S D, et al. Regulation of adrenal glucocorticoid synthesis by interleukin-10: a preponderance of IL-10 receptor in the adrenal zone fasciculate. Brain Behave Immun. 2006; 20(5): 460-468. D0I: 10.1016/j.bbi.2005.09.003

29. Haddad JJ, Hanbali LH. The anti-inflammatory and immunomodulatory activity of thymulin peptide is NF-kB dependent and involves the downregulation of I kB-a. Am J Med Biol Res. 2013; 1(2):41-49. DOI: 10.12691/ajmbr-1-2-2.

30. Kang Z, Liu L, Spangler R, Spear C, Wang C, Gulen MF, et al. IL-17-induced Act1-mediated signaling is critical for cuprizone-induced demyelination. J Neurosci. 2012; 32(4):8284 - 8292. DOI: 10.1523/JNEUROSCI.0841-12.2012.

31. Serra-de-Oliveira N, Boilesen SN, Prado de França Carvalho C, Lesueur-maluf L, Zollner R, Spadari RC, et al. Behavioural changes observed in demyelination model shares similarities with white matter abnormalities in humans. Behav Brain Res. 2015; 287:265-275. D0I: 10.1016/j.bbr.2015.03.038.

32. Lysyanui NI. Podviyna rol' mikrogliï v patogenezi rozsiyanogo sklerozu [Double role of microglyia in pathogenesis of multiple sclerosis]. Ukraïns'kiy nevrologichniy zhurnal - Ukrainian Neurological Journal. 2018; 3-4:5-10. DOI: https://doi.org/10.30978/UNJ2018-3-5. [In Ukrainian]

33. Brodie $C$. Differential effects of Th1 and Th2 derived cytokines on NGF synthesis by mouse astrocytes. FEBS Lett. 1996; 394:117-120.

34. Furusho $M$, Roulois AJ, Franklin RJ, Bansal $R$. Fibroblast growth factor signaling in oligodendrocyte-lineage cells facilitates recovery of chronically demyelinated lesions but is redundant in acute lesions. Glia. 2015; 63(10):1714-1728. DOl:10.1002/glia 22838.

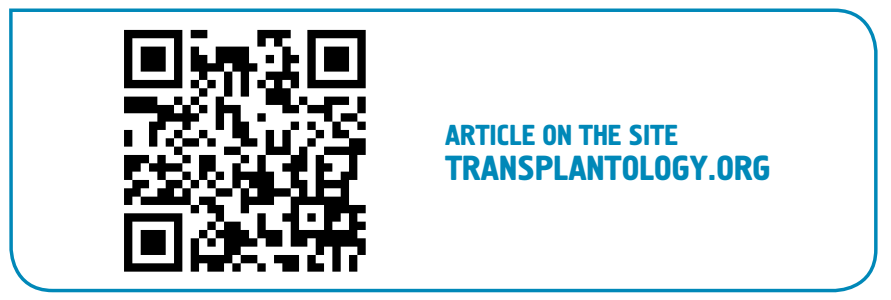

The authors indicate no potential conflicts of interest. 